\title{
TINGKAT KEPEMIMPINAN EFEKTIF PADA MAHASISWA PROGRAM STUDI AKUNTANSI ANGKATAN 2017 UNIVERSITAS INFORMATIKA DAN BISNIS INDONESIA
}

\author{
Rachmawati Windyaningrum \\ Fakultas Komunikasi dan Desain, Universitas Informatika dan Bisnis Indonesia \\ Email : rachma.ningrum@unibi.ac.id
}

\begin{abstract}
Abstrak
Jiwa kepemimpinan menjadi nilai penting yang harus dimiliki setiap mahasiswa. Mahasiswa sebagai agen perubahan, saat ini tidak hanya mampu memberikan pemikiran kritis saja, namun juga harus disertai sikap bertanggungjawab, mampu mencapai tujuan, dan mengatasi perubahan maupun membuat keputusan yang tepat. Universitas Informatika dan Bisnis Indonesia (UNIBI) memiliki kekhasan untuk membekali mahasiswa sebagai calon sarjana yang berjiwa pemimpin dan berpikir secara global melalui pemberian mata kuliah kepemimpinan global. Penelitian ini bertujuan untuk mengukur tingkat kepemimpinan efektif pada mahasiswa Program Studi Akuntansi UNIBI berdasarkan aspek kepemimpinan gaya dasar dan gaya efektif. Metode penelitian ini menggunakan pendekatan kuantitatif dengan metode survey pengukuran kepemimpinan William J. Reddin, kepada 15 orang mahasiswa Program Studi Akuntansi angkatan 2017 yang menjadi populasi penelitian. Populasi tersebut dipilih berdasarkan kuota sampling yakni total mahasiswa yang mengikuti kelas mata kuliah Global Leadership. Adapun hasil penelitian berdasarkan aspek kepemimpinan gaya dasar didapatkan sebanyak $66,6 \%$ mahasiswa memiliki orientasi tinggi pada tugas atau pekerjaan dan tinggi pada hubungan. Aspek kepemimpinan efektif sebanyak $73 \%$ mahasiswa memiliki keterampilan memimpin yang lebih efektif. Kesimpulan tingkat kepemimpinan dasar mahasiswa tinggi dan kepemimpinan efektif sangat tinggi.
\end{abstract}

\section{Kata Kunci : Kepemimpinan, Kepemimpinan Efektif, Mahasiswa}

\begin{abstract}
Leadership becomes an important value that must be possessed by every student. Students as agents of change, are not only able to provide critical thinking, but must also be accompanied by a responsible attitude, able to achieve goals, and overcome changes and make the right decisions. The University of Informatics and Business of Indonesia (UNIBI) has the uniqueness to equip students as prospective scholars who are leaders and think globally through the provision of global leadership courses. This study aims to measure the level of effective leadership of UNIBI Accounting Study Program students based on aspects of basic style of leadership and effective style. This research method uses a quantitative approach with the survey method of leadership measurement of William J. Reddin, to 15 students of the 2017 Accounting Study Program who are the research population. The population was chosen based on the sampling quota, which is the total number of students taking Global Leadership classes. The results of research based on aspects of basic style leadership found $66.6 \%$ of students have a high orientation to the task or job and high on relationships. Aspects of effective leadership as many as $73 \%$ of students have more effective leadership skills. Conclusions the basic level of student leadership is high and effective leadership is very high.
\end{abstract}

\section{Keywords : Leadership, Effective Leadership, Students}




\section{PENDAHULUAN}

Kepemimpinan menjadi sebuah dasar atau bagian dari kompetensi manusia dalam melakukan manajemen diri maupun kelompok. Jiwa kepemimpinan sangat diperlukan untuk membangun sebuah organisasi dalam mencapai tujuan. Kepemimpinan tidak hanya diperlukan bagi para petinggi-petinggi organisasi, perusahaan, atau instansi. Namun kepemimpinan harus dapat diasah atau dikembangkan sejak dini oleh kaum muda. Hal tersebut didasarkan pada faktor terpenting dalam kepemimpinan adalah manusia itu sendiri.

Kaum muda harus memiliki jiwa kepemimpinan dalam mengatasi perubahan zaman maupun pengambilan keputusan yang sesuai dengan kebutuhan perkembangan zaman serta tujuan organisasi. Kepemimpinan menurut Bertocci (2009) adalah ...suatu interaksi antara anggota atau kelompok. Pemimpin adalah agen perubahan, orang yang tindakannya memengaruhi orang lain lebih dari pada tindakan orang lain memengaruhi mereka. Kepemimpinan terjadi ketika satu anggota kelompok menstimulus motivasi atau kompetensi orang lain dalam kelompok. Berdasarkan pengertian tersebut, dapat terlihat pemimpin identik dengan agen perubahan yang dapat memengaruhi orang lain mencapai tujuan kelompok.

Sebagai agen perubahan, jiwa kepemimpinan dapat mulai terlihat pada kelompok mahasiswa. Mahasiswa merupakan orang yang sedang menenpuh pendidikan tinggi pada perguruan tinggi. Secara peran, mahasiswa selalu dikaitkan dengan roda penggerak yang kuat dalam tatanan sosial masyarakat. Menurut Avuan Rizki (2018), hakikat mahasiswa adalah seorang akademisi yang memiliki beban untuk mengimplementasikan ilmunya pada masyarakat. Hakikat tersebut juga memberikan gambaran peran yang penting dalam kehidupan bermasyarakat. Secara umum Avuan Rizki mengatakan terdapat tiga peran mahasiswa yakni iron stock, agen of change, dan social control (Rizki, 2018). Iron stock dijelaskan bahwa mahasiswa mayoritas adalah golongan muda yang berusia produktif dijadikan sebagai aset, cadangan, harapan bangsa untuk masa depan. Secara ringkas mahasiswa berperan sebagai generasi penerus. Agen of change dijelaskan sebagai agen -agen pembawa perubahan di masyarakat. Mahasiswa dapat bergerak bersama-sama secara kelompok atau individu dengan membawa tujuan perubahan sesuai bidang keilmuannya. Social control dikatakan sebagai pengontrol sosial, mahasiswa dapat membantu menyelesaikan masalah sesuai disiplin ilmu, advokasi, dan menyuarakan aspirasi kepada pemerintah (Rizki, 2018).

Melihat pelbagai peran mahasiswa tersebut sangat erat kaitannya dengan jiwa kepemimpinan yang harus dimiliki mahasiswa. Kepemimpinan atau jiwa kepemimpinan tidak dapat dilepaskan dari personal pemimpin itu sendiri. Seperti yang dijelaskan oleh Nyoto (2019) dalam buku Manajemen Sumber Daya Manusia yakni, kepemimpinan mengarah kepada kemampuan individu; kepemimpinan adalah hubungan interaksi antara si pemimpin dengan pengikut; kepemimpinan menggantungkan diri pada sumber-sumber dalam dirinya; kepemimpinan diarahkan untuk kepentingan si pemimpin; kepemimpinan bersifat hubungan personal yang berpusat pada diri pemimpin, pengikut dan situasi.

Hal tersebut menguatkan bahwa secara personal, kepemimpinan bisa dibentuk dan dikembangkan agar dapat diimplementasikan dengan efektif. Pembentukkan jiwa kepemimpinan pada mahasiswa ini dapat dilakukan salah satunya dengan muatan mata kuliah di perguruan tinggi. Universitas Informatika dan Bisnis Indonesia (UNIBI) salah satu perguruan tinggi swasta yang memiliki muatan mata kuliah universitas terkait kepemimpinan. Mata kuliah tersebut adalah Global Leadership atau Kepemimpinan Global. Capaian mata kuliah tersebut adalah membentuk kemampuan mepemimpin dan memiliki pandangan global bagi mahasiswa. Capaian tersebut menjadi representasi kekhasan UNIBI dalam menciptakan lulusan yang memiliki 
karakter kuat dan jiwa enterpreneurship. Mata kuliah ini dipelajari oleh mahasiswa dari seluruh program studi yang ada di UNIBI, salah satunya Program Studi Akuntansi. Program Studi Akuntansi UNIBI membekali mahasiswanya dengan jiwa kepemimpinan, dikarenakan mahasiswa tersebut harus mampu memberikan pengaruh atau keyakinan kepada klien terkait hasil pelaporan keuangan maupun perpajakan.

Hal tersebut menjadi dasar penelitian ini, karena masih ditemukan mahasiswa Program Studi Akuntansi UNIBI yang kurang percaya diri dalam memimpin kelompok, terutama angkatan 2017 yang mengikuti kelas Global Leadership. Kepemimpinan yang terjadi pada mahasiswa Akuntansi tersebut hanya didominasi oleh Ketua Kelas dan beberapa mahasiswa yang memiliki usia di atas usia rata-rata mahasiswa satu kelasnya. Fenomena ini menimbulkan kesenjangan yakni adanya ketidaksesuasian representasi kepemimpinan yang terlihat pada aktivitas akademik dengan latar belakang kehidupan mahasiswa tersebut. Mayoritas mahasiswa pada kelas tersebut sudah memiliki pengalaman pekerjaan dengan tingkatan bervariasi, mulai entry level, middle level, hingga ada yang menjadi pemilik suatu bisnis.

\subsection{Identifikasi Masalah}

Adapun identifikasi masalah dalam penelitian ini adalah,

1. Seberapa besar tingkat kepemimpinan dasar pada mahasiswa Program Studi Akuntansi Angkatan 2017 UNIBI?

2. Seberapa besar tingkat kepemimpinan efektif pada mahasiswa Program Studi Akuntansi Angkatan 2017 UNIBI?

\subsection{Tujuan Penelitian}

Tujuan penelitian ini adalah

1. Untuk mengetahui tingkat kepemimpinan dasar pada mahasiswa Program Studi Akuntansi Angkatan 2017 UNIBI.

2. Untuk mengetahui tingkat kepemimpinan efektif pada mahasiswa
Fenomena tersebut seharusnya menjadikan mahasiswa lebih aktif, kreatif, dan inisiatif dalam kegiatan akademik di kelas, sehingga akan terlihat potensi jiwa kepemimpinan yang dimiliki masing-masing mahasiswa.

Berdasarkan fenomena tersebut, penelitian ini akan menguji tingkat kepemimpinan yang dimiliki mahasiswa Akuntansi 2017 agar dapat melihat potensi gaya kepemimpinan dasar maupun gaya kepemimpinan efektif. Untuk mengukur tingkat kepemimpinan tersebut peneliti menggunakan metode survey dengan instrumen Reddin Test. Penelitian ini akan memberi kebaharuan mengenai gaya kepemimpinan dapat diidentifikasi pada mahasiswa yang merupakan golongan muda sebagai agen perubahan. Pada akhirnya, penelitian ini akan memberikan manfaat praktis sebagai referensi serta evaluasi bagi muatan materi perkuliahan Global Leadership yang menjadi ciri khas UNIBI dalam membekali soft skills pada calon lulusannya. Oleh karena itu peneliti menarik rumusan masalah penelitian tentang seberapa besar tingkat kepemimpinan efektif pada mahasiswa Program Studi Akuntansi Angkatan 2017 UNIBI?.

Program Studi Akuntansi Angkatan 2017 UNIBI.

\section{KAJIAN PUSTAKA}

Kepemimpinan

Kepemimpinan menjadi sebuah kemampuan yang harus dimiliki setiap manusia. Kepemimpinan memuat upaya pengaruh untuk mencapai tujuan baik secara individual maupun kelompok. Seperti yang dinyatakan Donelly (1999), bahwa pemimpin adalah agen perubahan yang dapat memengaruhi orang lain. Pimpinan menjadi sosok sentral dalam fungsi directing (pengarahan) terhadap tujuan yang ingin dicapai (Nyoto, 2019). Selain menjadi sosok sentral dalam pengarahan, kepemimpinan juga dapat diartikan sebaga kemampuan untuk 
memengaruhi kelompok menuju pencapaian tujuan (Storey, 2004).

Kepemimpinan dapat terbangun dari faktor-faktor personal, interpesonal dan situasi yang mendukung seseorang untuk mewujudkan jiwa kepemimpinan. Seperti menurut Chung dan Megginson (1981), kepemimpinan adalah suatu fenomena sosial yang komplek yang dipengaruhi oleh sejumlah faktor personal, interpersonal, dan organisasisasional yang meliputi sifat-sifat personal pemimpin, perilaku pemimpin, dan faktor-faktor situasional (Nyoto, 2019).

Berdasarkan definisi para ahli tersebut, dapat disimpulkan bahwa kepemipinan merupakan kemampuan untuk memengaruhi orang lain dalam mencapai tujuan, dengan dipengaruhi faktor personal, interpersonal, dan situasional dalam lingkungan organisasi, kelompok, maupun individu tersebut.

Kepemimpinan yang baik harus memiliki kualitas sebagai bentuk proses kepemimpinan. Kualitas tersebut terdiri dari:

1. Merumuskan visi strategis

2. Mengomunikasikan visi kepada orang lain

3. Membangun kepercayaan melalui keahlian teknis, pengambilan risiko pribadi, pengorbanan diri,dan perilaku tidak kovensional

4. Menunjukkan cara untuk mencapai visi melalui permodelan peran, pemberdayaan dan taktik yang tidak konvensional (Bertocci, 2009).

\section{2..2 Karakteristik Kepemimpinan}

Karakteristik pemimpin identik dengan bakat atau sifat yang dimiliki secara personal. Seperti penjelasan dari Ralph M. Stogdill bahwa para pemimpin memang lebih cerdas daripada pengikutnya (Bertocci, 2009). Stogdill menjelaskan kepempimpinan ditandai dengan sifat-sifat yang dikelompokkan yakni,

1. Capacity, meliputi kecerdasan, kewaspadaan, kemampuan. Bicara, keaslian, dan kemampuan nilai
2. Achievement, meliputi gelar kesarjanaan, pengetahuan, keberhasilan dan olahraga.

3. Responsibility, meliputi mandiri berinisiatif, tekun, agresif, percaya diri, dan berkeinginan untuk maju.

4. Participation, meliputi aktif, kemampuan bergaul, dapat bekerja sama, mudah menyesuaikan diri dan humoris.

5. Status, meliputi kedudukan sosial ekonomi dan ketenaran.

6. Situation, meliputi mental dan status yang baik (Nyoto, 2019).

\subsection{Gaya Kepemimpinan}

Gaya kepemimpinan menjadi bentuk atau cara seseorang dalam mengarahkan atau memengaruhi orang lain. Menurut Kaplan dan Norton (2001), gaya kepemimpinan merupakan racikan yang paling kritis bagi keberhasilan kinerja organisasi secara komperhensif. Dijelaskan oleh Thoha (2001) bahwa gaya kepemimpinan merupakan norma perilaku yang digunakan oleh seseorang pada saat mencoba untuk memengaruhi perilaku orang lain. Gaya kepemimpinan dalam penelitian ini mengadopsi gaya kepemimpinan tiga dimensi efektif William J. Reddin.

Dikutip Adiwilaga (2018) dalam buku Kepemimpinan Pemerintahan Indonesia : Teori dan Praktek, Reddin memaparkan efektivitas kepemimpinan dalam tiga hal pokok yakni pendekatan model tiga dimensi. Tiga dimensi ini terdapat pembagian berdasarkan gaya tidak efektif, gaya dasar, dan gaya efektif. Gaya tidak efektif berada pada urutan terbawah yang terdiri dari:

1. Gaya pencinta kompromi, yaitu pemimpin memberikan perhatian yang besa pada tugas pekerjaan dan hubungankerja berdasarkan kompromi. Pemimpin yang menggunakan gaya ini merupakan pembuat keputusan yang jelek karena banyak tekanan bawahan yang memengaruhinya.

2. Gaya misionari, yaitu pemimpin memperhatikan maksimal pada 
hubungan kerja dan minimal terhadap tugas. Pemimpin yang menggunakan gaya ini hanya menilai keharmonisan sebagai tujuan dirinya sendiri.

3. Gaya otokrat, yaitu pemimpin memberikan perhatian yang maksimal pada tugas dan minimal pada hubungan kerja. Pemimpin yang menggunakan gaya ini tidak percaya pada orang lain, tidak menyenangkan, dan hanya tertarik pada pekerjaan yang cepat dan selesai.

4. Gaya lari dari tugas, yaitu pemimpinsama sekali tidak memberikan perhatian pada tugas dan hubungan kerja. Pemimpin yang menggunakan gaya ini tidak peduli pada tugas dan orang lain (Adiwilaga, 2018).

Dimensi berikutnya yang berada urutan tengah adalah gaya dasar. Perilaku kepemimpinan pada gaya dasar berorientasi pada tugas dan hubungan. Gaya dasar memiliki empat gaya yakni:

1. Gaya dasar terpadu menunjukkan orientasi yang tinggi pada tugas atau pekerjaan dan juga pada hubungan atau orang.

2. Gaya berhubungan yang menunjukkan orientasi pada hubungan atau orang yang. tinggi dan rendah pada tugas atal6. pekerjaan.

3. Gaya terpisah yang menunjukkan orientasi rendah pada hubungan orang dan pekerjaan atau tugas.

4. Gaya pengabdian yang menunjukkan orientasi pada tugas atau pekerjaan yang tinggi dan orientasi pada hubungan atau orang yang rendah ${ }^{1}$.

Dimensi terakhir atau dimensi yang urutannya teratas adalah gaya efektif. Gaya efektif terdiri dari:

1. Gaya eksekutif, yaitu pemimpin banyak memberikan perhatian pada tugas-tugas pekerjaan dan hubungan kerja. Pemimpin

${ }^{1}$ https://ensiklopediapramuka.com, waktu akses 03 Maret 2020, 16.00 wib ini disebut motivator yang baik, mau dan mampu memberikan standar kerja yang tinggi, mau mengenal perbedaan karakteristik individu, mau menggunakan kerja tim dalam manajemen.

2. Gaya pecinta pengembang, yaitu pemimpin memberikan perhatian maksimal pada hubungan kerja dan minimal terhadap tugas. Pemimpin ini mempunyai kepercayaan implisit terhadap orang-orang yang bekerja dalam birokrasi dan sangat memperhatikan pengembangan individu.

3. Gaya otokratis yang baik, yaitu pemimpin memberikan perhatian maksimal pada tugas dan minimal pada hubungan kerja. Pemimpin ini mengetahui secara tepat yang diinginkan dan cara mencapainya tanpa menyebabkan keengganan pihak bawahannya.

4. Gaya birokrat, pemimpin memberika dedikasinya secara maksimal pada tugas dan hubungan kerja. Pemimpin ini sangat tertarik pada aturan-aturan ydan mengontrol pelaksanaannya secara teliti (Adiwilaga, 2018).

\section{METODE PENELITIAN}

Penelitian ini menggunakan pendekatan kunatitatif dengan metode survei. Tujuan menggunakan metode survei untuk menggambarkan suatu fenomena yang hasilnya dapat digeneralisasikan (Kriyantono, 2006). Penelitian ini akan mendeskripsikan tingkat kepemimpinan yang dimiliki mahasiswa dengan instrumen kepemimpinan efektif William J. Reddin. Instrumen tersebut dibuat dalam bentuk kuisoner agar dapat mengukur masalah penelitian yang diajukan kepada responden. Kuisoner ini disebarkan kepada mahasiswa Program Studi Akuntansi UNIBI yang mengikuti kelas Global Leadership tahun akademik 2019.2020. Mahasiswa tersebut 
menjadi populasi dalam penelitian ini yang berjumlah 15 orang. Guna menghasilkan sampel yang dapat merepresentasikan populasi tersebut, maka peneliti menggunakan teknik kuota sampling dalam pengambilan sampel. Dengan teknik tersebut peneliti mengambil jumlah sampel sesuai dengan total keseluruhan populasi sebanyak 15 orang mahasiswa. Hal ini dipilih, karena populasi dalam penelitian ini terbatas yakni mahasiswa angkatan 2017 yang mengikuti kelas Global Leadership.

Operasionalisasi variabel pada penelitian ini menggunakan penilaian gaya dan adaptabilitas kepemimpinan William J. Reddin yang terdiri dari:

Tabel 1. Operasionalisasi Variabel

\begin{tabular}{lll}
\hline Variabel & $\begin{array}{l}\text { Sub } \\
\text { Variabel }\end{array}$ & Indikator \\
\hline Gaya dan & 1. Gaya & 1. Delegating \\
adaptabilitas & Dasar & 2. \\
kepemimpinan & 2. Gaya & Participating \\
& Efektif & 3. Selling \\
& & 4. Telling \\
\hline
\end{tabular}

Sumber : Olah data penulis, 2020

Teknik analisa data pada penelitian ini menggunakan statistika deskriptif. Menurut Sudijono (2007) statistika deskriptif adalah statistik yang digunakan untuk menganalisis data dengan cara mendeskripsikan atau menggambarkan data yang telah terkumpul sebagaimana adanya tanpa bermaksud membuat kesimpulam yang berlaku untuk umum atau generalisasi.

Analisa data dimulai dari menghitung hasil skoring yang didapat sesuai rumusan menggunakan penilaian gaya dan adaptabilitas kepemimpinan William J. Reddin yakni,

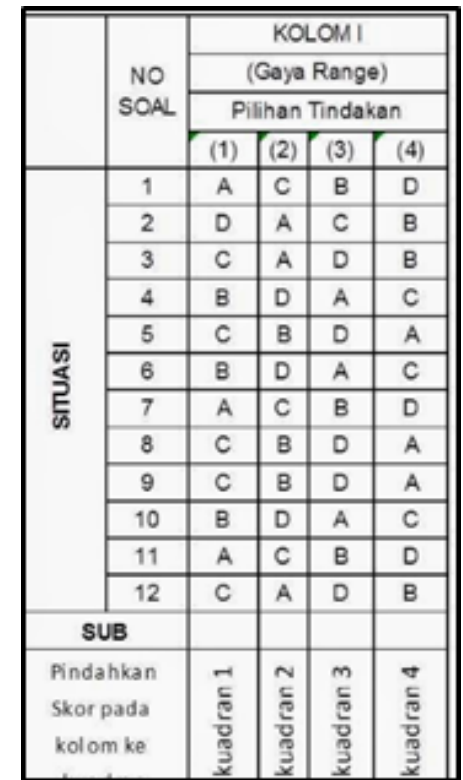

Gambar 1. Kolom Perhitungan Gaya Dasar, sumber :

http://www.ensiklopediapramuka.com/2014/04/ kepemimpinan-assesment-test-gaya.html, 2020

Berdasarkan gambar tersebut jawaban A bernilai 1, B bernilai 2, C bernilai 3, D bernilai 4. Setelah diberikan nilai, selanjutnya akan dijumlahkan sesuai kolom kuadran. Untuk hasil analisis merujuk pada nilai tertinggi yang diperoleh pada kolom kuadran.

Untuk mengukur tingkat efektivitas kepemimpinan menggunakan range skala skor 24 hingga +24 dari hasil penjumlahan dan pengalian skor di setiap kolomnya. Berikut gambar perhitungan efektivitas kepemimpinan, 


\begin{tabular}{|c|c|c|c|c|c|}
\hline & \multirow{4}{*}{$\begin{array}{l}\text { NO } \\
\text { SOAL }\end{array}$} & \multicolumn{4}{|c|}{ KOLOM II } \\
\hline & & \multicolumn{4}{|c|}{ (Gaya Range) } \\
\hline & & \multicolumn{4}{|c|}{ Pilihan Tindakan } \\
\hline & & (a) & (b) & (c) & (d) \\
\hline \multirow{12}{*}{$\begin{array}{l}\overline{\text { कू }} \\
\text { ह }\end{array}$} & 1 & $D$ & $B$ & $\mathrm{C}$ & A \\
\hline & 2 & B & D & C & A \\
\hline & 3 & $\mathrm{C}$ & $B$ & $A$ & $D$ \\
\hline & 4 & $B$ & $D$ & A & C \\
\hline & 5 & $A$ & $D$ & $B$ & C \\
\hline & 6 & $C$ & A & B & D \\
\hline & 7 & A & C & $\mathrm{D}$ & B \\
\hline & 8 & $\mathrm{C}$ & $B$ & $\mathrm{D}$ & A \\
\hline & 9 & $A$ & $D$ & $B$ & C \\
\hline & 10 & $B$ & $\mathrm{C}$ & A & $D$ \\
\hline & 11 & $A$ & $\mathrm{C}$ & $\mathrm{D}$ & $B$ \\
\hline & 12 & $\mathrm{C}$ & $A$ & $\mathrm{D}$ & $B$ \\
\hline \multicolumn{6}{|c|}{ SUB TOTAL } \\
\hline \multirow{2}{*}{\multicolumn{2}{|c|}{$\begin{array}{l}\text { Kalikan } \\
\text { dengan }\end{array}$}} & (a) & (b) & (c) & (d) \\
\hline & & -2 & -1 & +1 & +2 \\
\hline
\end{tabular}

Gambar 2. Kolom Perhitungan Efektivitas Kepemimpinan, sumber :

http://www.ensiklopediapramuka.com/2014/04/ kepemimpinan-assesment-test-gaya.html, 2020

Selanjutnya dari hasil penghitungan skoring tersebut, maka dilakukan analisis statistika deskriptif dengan teknik persentase dengan rumus besaran persentase sebagai berikut,

$\%=\mathrm{n} / \mathrm{N} \times 100$

Keterangan :

$\mathrm{n}=$ nilai yang diperoleh

$\mathrm{N}=$ Jumlah seluruh nilai (Ali, 1992, dalam Sudijono, 2007)

Setelah data dihitung menggunakan rumus besaran persentase, selanjutnya data penelitian diinterpretasikan berdasarkan kriteria skor berikut,

Tabel 2. Kriteria Interpretasi Skor

\begin{tabular}{ll}
\hline Skor Persentase & Interpretasi \\
\hline $0 \%-20 \%$ & Sangat rendah \\
\hline $21 \%-40 \%$ & Rendah \\
\hline $41 \%-60 \%$ & Cukup \\
\hline $61 \%-80 \%$ & Tinggi \\
\hline $81 \%-100 \%$ & Sangat Tinggi \\
\hline
\end{tabular}

Sumber : Sudijono, 2007

\section{HASIL DAN PEMBAHASAN}

\subsection{Hasil Penelitian}

Kepemimpinan yang terjadi pada mahasiswa Program Studi Akuntansi angkatan 2017 UNIBI terlihat pada pelaksanaan kelas mata kuliah Global Leadership. Kepemimpinan yang terlihat hanya pada beberapa mahasiswa saja. Jiwa kepemimpinan tersebut terwujud dalam bentuk insiatif, keaktifan, tanggung jawab, kreativitas, dan kemampuan mengarahkan. Namun jiwa kepemimpinan tersebut dapat terlihat pada Ketua Kelas, mahasiswa yang memiliki usia lebih tua, dan mahasiswa yang memiliki pengalaman pekerjaan sebagai manager atau supervisor. Untuk mahasiswa lainnya masih belum terlihat karakteristik jiwa kepemimpinan, tetapi mereka memiliki potensi yang sama. Lebih jelas akan dijabarkan melalui data identitas responden mengenai jenis kelamin, usia, dan latar belakang pekerjaan.

Berdasarkan hasil survey dari 15 orang mahasiswa Program Studi Akuntansi angkatan 2017 yang mengikuti kelas Global Leadership mayoritas sebesar $73 \%$ berjenis kelamin perempuan.

Tabel 3. Jenis Kelamin Mahasiswa

\begin{tabular}{llll}
\hline No & Jenis Kelamin & $\mathrm{f}$ & $\%$ \\
& & & \\
\hline $\mathbf{1}$ & Perempuan & 11 & 73 \\
\hline $\mathbf{2}$ & Laki-laki & 4 & 27 \\
\hline Total & & 15 & 100 \\
\hline
\end{tabular}

Sumber : Olah data peneliti, 2020

Untuk usia mahasiswa Program Studi Akuntansi angkatan 2017 didominasi usia dewasa muda yakni 21-23 tahun. Usia tersebut menunjukkan sebanyak $73 \%$, sehingga mahasiswa memiliki potensi kepemimpinan yang masih dapat dikembangkan dan diasah saat menempuh pendidikan tinggi. Hal ini dijelaskan oleh Avian Rizki (2019) bahwa mahasiswa biasanya termasuk golongan muda, diharapkan sebagai bagain dari iron stock untuk kaderisasi generasi. Kaderisasi generasi ini menjadi dasr untuk mengasah 
potensi kepemimpinan pada setiap personal mahasiswa.

Tabel 4. Usia Mahasiswa

\begin{tabular}{|l|l|l|l|}
\hline No & $\begin{array}{l}\text { Usia } \\
\text { Mahasiswa }\end{array}$ & F & \% \\
\hline 1 & $\begin{array}{l}17-20 \\
\text { Tahun }\end{array}$ & 0 & 0 \\
\hline 2 & $\begin{array}{l}21-23 \\
\text { Tahun }\end{array}$ & 11 & 73 \\
\hline 3 & $>24$ Tahun & 4 & 27 \\
\hline \multicolumn{2}{|l|}{ Total } & 15 & 100 \\
\hline
\end{tabular}

Sumber: Olah data peneliti, 2020

Mahasiswa Program Studi Akuntansi angkatan 2017 yang mengikuti kelas Global Leadership sudah memiliki pengalaman bekerja sebelumnya. Mahasiswa tersebut, bekerja pada pelbagai bidang, mulai bidang akuntansi, penjualan, produksi, dan lainnya. Pekerjaan mahasiswa tersebut memerlukan kemampuan mengarahkan maupun memimpin sebuah tim. Adapun jenis pekerjaan yang dimiliki mahasiswa tersebut adalah,

Tabel 5. Pekerjaan Mahasiswa

\begin{tabular}{llll}
\hline No & $\begin{array}{l}\text { Jenis } \\
\text { Pekerjaan }\end{array}$ & f & $\%$ \\
\hline $\mathbf{1}$ & Swasta & 14 & 93 \\
\hline $\mathbf{2}$ & Wirausaha & 1 & 7 \\
\hline $\mathbf{3}$ & Lain-lain & 0 & 0 \\
\hline \multicolumn{2}{l}{ Total } & 15 & 100 \\
\hline \multicolumn{2}{l}{ Sumber : Olah data peneliti, 2020 }
\end{tabular}

Berdasarkan tabel 4 diketahui pekerjaan mahasiswa sangat tinggi persentasenya hingga 93\% bekerja disektor swasta. Dengan latar pendidikan akuntansi jenis pekerjaan di perusahaan swasta ini juga harus didukung oleh kemampuan memimpin terutama memimpin dalam sebuah tim, divisi atau bagian. Melalui kelas Global Leadership, mahasiswa tersebut dibekali konsep dasar kepemimpinan, mind set kepemimpinan, karakteristik kepemimpinan, hingga gaya kepemimpinan. Gaya kepemimpinan ini yang dapat terlihat pada personal mahasiswa ketika memimpin suatu tim. Penelitian ini mengukur tingkat kepemimpinan yang dimiliki mahasiswa dengan aspek kepemimpinan dasar dan kepemimpinan efektif.

\subsubsection{Tingkat Kepemimpinan Mahasiswa Pada Aspek Gaya Dasar}

Kepemimpinan dasar digunakan untuk melihat tujuan atau orientasi mahasiswa dalam memimpin sebuah tim. Kepemimpinan dasar yang digunakan menggunakan konsep kepemimpinan William J Reddin. Kepemimpinan dasar Reddin menjelaskan kepemimpinan yang berorientasi pada orang atau pada tugas. Pada mahasiswa Program Studi Akuntansi angkatan 2017 yang mengikuti kelas Global Leadership memiliki gaya kepemimpinan dasar yang masuk pada kuadaran 1, kuadran 2 dan kuadran 3.

Tabel 6. Hasil Skor Gaya Kepemimpanan Dasar

\begin{tabular}{cccccc}
\hline R & \multicolumn{5}{c}{ Skoring } \\
\cline { 2 - 5 } & \multicolumn{1}{c}{ Kuadran } & \multicolumn{2}{c}{ Kuadran } & Kuadran & \multicolumn{2}{c}{ Kuadran } \\
$\mathbf{1}$ & 6 & 20 & 9 & 0 \\
\hline $\mathbf{2}$ & 2 & 24 & 7 & 0 \\
\hline $\mathbf{3}$ & 12 & 9 & 3 & 3 \\
\hline $\mathbf{4}$ & 8 & 13 & 8 & 3 \\
\hline $\mathbf{5}$ & 9 & 17 & 4 & 0 \\
\hline $\mathbf{6}$ & 12 & 16 & 5 & 0 \\
\hline $\mathbf{7}$ & 0 & 29 & 0 & 4 \\
\hline $\mathbf{8}$ & 15 & 12 & 1 & 0 \\
\hline $\mathbf{9}$ & 16 & 6 & 2 & 0 \\
\hline $\mathbf{1 0}$ & 10 & 7 & 8 & 0 \\
\hline $\mathbf{1 1}$ & 8 & 11 & 5 & 1 \\
\hline $\mathbf{1 2}$ & 6 & 11 & 10 & 7 \\
\hline $\mathbf{1 3}$ & 5 & 10 & 12 & 0 \\
\hline $\mathbf{1 4}$ & 9 & 16 & 2 & 0 \\
\hline $\mathbf{1 5}$ & 9 & 12 & 7 & 3 \\
\hline
\end{tabular}

Sumber : Olah data peneliti, 2020

Berdasarkan tabel di atas terlihat skor dari setiap responden bervariasi untuk 
mengetahui gaya kepemimpinan dasar yang dimiliki. Skor gaya kepemimpinan dasar paling tinggi terisi pada kuadran 2 mulai dari range 17 sampai 29. Selain itu, terdapat pula responden yang memiliki skor tertinggi pada kuadran 1 mulai dari range 12 sampai 16 . Kuadran yang juga memiliki skor cukup tinggi yakni kuadran 3 pada skor 12. Skor setiap kuadran tersebut menandakan kecenderungan terbesar responden masuk pada kuadran gaya kepemimpinan yang dominan. Dijelaskan oleh Reddin (dalam Adiwilaga, 2018) efektivitas kepemimpinan terdapat tiga dimensi. Dimensi tersebut yakni gaya tidak efektif, gaya dasar, dan gaya efektif. Dimensi kepemimpinan gaya dasar terdiri dari empat kuadran yakni gaya terpadu, gaya berhubungan, gaya terpisah, dan gaya pengabdian (Adiwilaga, 2018).

Kuadran 1 merupakan gaya pengabdian yang menunjukkan orientasi pada tugas atau pekerjaan yang tinggi dan orientasi pada hubungan atau orang yang rendah, sehingga responden yang masuk pada kuadran ini lebih cenderung memiliki tata kerja yang terstruktur, namun kurang peduli pada anggota tim. Kuadran 2 merupakan gaya terpadu yang menunjukkan orientasi yang tinggi pada tugas atau pekerjaan dan juga pada hubungan atau orang, sehingga responden yang masuk pada kuadran ini mampu memimpin dengan memenuhi kebutuhan kelompok mencapai tujuan. Kuadran 3 merupakan gaya berhubungan yang menunjukkan orientasi pada hubungan atau orang yang tinggi dan rendah pada tugas atau pekerjaan. Responden yang masuk pada kuadran ini cenderung memberikan kemudahan untuk berkembang pada anggota timnya untuk mencapai sebuah tujuan ketimbang pekerjaan, sehingga lebih banyak menciptakan hubungan yang

2 https://ensiklopediapramuka.com, waktu akses 03 Maret 2020, 16.00 wib harmonis diantara anggota tim. Kuadran 4 merupakan gaya terpisah yang menunjukkan orientasi rendah pada hubungan orang dan pekerjaan atau tugas. Responden yang masuk pada kuadran ini cenderung memberikan delegasi wewenang atau pekerjaan pada anggota tim. Selain itu, tidak memberikan struktur yang jelas dan dukungan moral yang baik pada anggota tim $^{2}$.

Dari tabel 5 tersebut secara deskriptif statistika dapat diperoleh data mayoritas responden memiliki kecenderungan kepemimpinan dengan gaya dasar terpadu. Responden berdasarkan tingkat skor yang didapat banyak memiliki nilai tertinggi pada kuadran 2. Selanjutnya, responden lain memiliki kecenderungan kepemimpinan dengan gaya pengabdian dan gaya berhubungan. Adapun penjelasan lebih rinci digambarkan pada tabel sebagai berikut,

Tabel 7. Tingkat Kepemimpinan Gaya Dasar

\begin{tabular}{|c|c|c|c|}
\hline No & Gaya Dasar & $\mathrm{F}$ & $\%$ \\
\hline 1 & Pengabdi & 4 & 26,6 \\
\hline 2 & Terpadu & 10 & 66,6 \\
\hline 3 & Berhubungan & 1 & 6,6 \\
\hline 4 & Terpisah & 0 & 0 \\
\hline Tot & & 15 & 100 \\
\hline
\end{tabular}

Tabel tersebut menggambarkan bahwa mahasiswa Program Studi Akuntansi UNIBI angkatan 2017 yang mengikuti kelas Global Leadership memiliki gaya terpadu sebanyak $66,6 \%$, gaya pengabdi $26,6 \%$, dan gaya berhubungan $6,6 \%$. Hal tersebut menunjukkan bahwa mahasiswa memiliki kecenderungan yang tinggi pada kepemimpinan dengan gaya terpadu. Mahasiswa tersebut sudah memiliki gaya kepemimpinan yang baik, karena berorientasi pada tugas atau pekerjaan dan hubungan dengan anggota tim yang tinggi. Selanjutnya mahasiswa yang memiliki gaya 
pengabdi memiliki kecenderungan yang rendah dan gaya berhubungan kecenderungan sangat rendah. Oleh karena itu, mahasiswa Program Studi Akuntansi UNIBI angkatan 2017 yang mengikuti kelas Global Leadership dapat dikatakan telah memiliki potensi kepemimpinan yang berorientasi pada pekerjaan dan anggota tim, sehingga jiwa kepemimpinanya dapat diimplementasikan baik saat menjadi mahasiswa maupun setelah lulus dan memasuki dunia kerja atau bermasyarakat.

4.1.2 Tingkat Kepemimpinan Mahasiswa Pada Aspek Gaya Efektif

Aspek gaya efektif dengan modek kepemimpinan tiga dimensi dapat dilihat dari pengukuran skala range kepemimpinan efektif dengan range -24 hingga +24 . Berdasarkan skala tersebut mahasiswa Program Studi Akuntansi UNIBI angkatan 2017 yang mengikuti kelas Global Leadership memiliki skor yang berada pada range kepemimpinan efektif. Berikut penjelasan skor aspek gaya efektif,

\begin{tabular}{crrrr} 
Tabel 8. Hasil Skor Gaya Efektif \\
Kepemimpinan \\
Responden & \multicolumn{5}{c}{ Range -24 hingga +24} \\
\hline $\mathbf{1}$ & -11 & -6 & 8 & 30 \\
\hline $\mathbf{2}$ & -16 & -4 & 6 & 15 \\
\hline $\mathbf{3}$ & -16 & -4 & 1 & 28 \\
\hline $\mathbf{4}$ & -10 & -9 & 7 & 22 \\
\hline $\mathbf{5}$ & -14 & -10 & 7 & 14 \\
\hline $\mathbf{6}$ & -10 & -10 & 11 & 14 \\
\hline $\mathbf{7}$ & -12 & 0 & 12 & 18 \\
\hline $\mathbf{8}$ & -18 & -8 & 4 & 12 \\
\hline $\mathbf{9}$ & -18 & -6 & 1 & 16 \\
\hline $\mathbf{1 0}$ & -10 & -1 & 12 & 14 \\
\hline $\mathbf{1 1}$ & -16 & -4 & 6 & 14 \\
\hline $\mathbf{1 2}$ & -12 & -4 & 14 & 20 \\
\hline $\mathbf{1 3}$ & -4 & -4 & 15 & 12 \\
\hline $\mathbf{1 4}$ & -12 & -6 & 5 & 14 \\
\hline $\mathbf{1 5}$ & -11 & -6 & 8 & 18 \\
\hline $\mathbf{1 0}$ & 0 & &
\end{tabular}

Sumber : Olah data peneliti, 2020

Tabel di atas menunjukkan bahwa dari 15 responden yang mengikuti tes kepemimpinan Reddin dapat terukur tingkat efektivitas kepemimpinannya berada dalam range -24 hingga +24 . Berdasarkan range tersebut mahasiswa memiliki kepemimpinan efektif. Namun efektivitas kepemimpinan mahasiswa terbagi menjadi efektivitas rendah dan tinggi, hal tersebut dilihat dari perolehan skor yang cenderung besar ke arah negatif. Gambaran mengenai tingkat rekapitulasi efektivitas kepemimpinan dapat terlihat pada tabel berikut,

\section{Tabel 9. Rekapitulasi Tingkat Efektivitas Kepemimpinan

\begin{tabular}{|l|l|l|l|}
\hline No & Efektivitas & F & $\%$ \\
\hline 1 & Efektif & 11 & 73 \\
\hline 2 & $\begin{array}{l}\text { Kurang } \\
\text { Efektif }\end{array}$ & 4 & 27 \\
\hline \multicolumn{2}{|l|}{ Total } & 15 & 100 \\
\hline
\end{tabular} \\ Sumber : Olah data peneliti, 2020}

Melihat tabel 8, dapat disimpulkan bahwa sebesar 73\% mahasiswa Program Studi Akuntansi UNIBI angkatan 2017 yang mengikuti kelas Global Leadership memiliki efektivitas kepemimpinan yang tinggi. Hal ini dilihat dari skor arah positif atau arah efektif lebih tinggi mendekati angka +24 atau lebih. Selanjutnya bagi mahasiswa yang kurang efektif hanya berjumlah $27 \%$ yang berarti rendah. Hal ini terlihat pada skor arah negatif atau arah kurang efektif yang lebih tinggi mendekati angkat -24. Oleh karena itu, mahasiswa tersebut memiliki potensi sebagai pemimpin yang efektif jika mahasiswa tersebut diberikan tugas memimpin baik dalam kelompok kuliah, organisasi, maupun di tempat pekerjaan.

\subsection{Pembahasan}

Mahasiswa Program Studi Akuntansi UNIBI angkatan 2017 yang mengikuti kelas Global Leadership merupakan mahasiswa yang memiliki potensi besar dalam memimpin sebuah kelompok kecil maupun kelompok besar. Berdasarkan hasil pengukuran tingkat kepemimpinan efektif mahasiswa tersebut memiliki tingkat kepemimpinan gaya dasar yang tinggi serta efektivitas kepemimpinan yang tinggi. Hal ini dapat menunjukkan mahasiswa dapat menjadi agen perubahan maupun pengarah untuk mencapai tujuan. Seperti yang dijelaskan 
Donelly (1999), bahwa pemimpin adalah agen perubahan yang dapat memengaruhi orang lain. Pimpinan menjadi sosok sentral dalam fungsi directing (pengarahan) terhadap tujuan yang ingin dicapai (Nyoto, 2019). Selain menjadi sosok sentral dalam pengarahan, kepemimpinan juga dapat diartikan sebagai kemampuan untuk memengaruhi kelompok menuju pencapaian tujuan (Storey, 2004).

Secara personal, mahasiswa tersebut memiliki gaya dasar yang dominan pada kuadran 2, yakni gaya terpadu. Gaya terpadu menunjukkan orientasi yang tinggi pada tugas atau pekerjaan dan juga pada hubungan atau orang. Reddin menjelaskan gaya dasar terpadu, jika berada pada gaya efektif maka akan masuk pada gaya eksekutif. Gaya ekskutif yaitu pemimpin banyak memberikan perhatian pada tugas-tugas pekerjaan dan hubungan kerja. Pemimpin yang menggunakan gaya ini disebut motivator yang baik, mau dan mampu memberikan standar kerja yang tinggi, mau mengenal perbedaan karakteristik individu, mau menggunakan kerja tim dalam manajemen (Adiwilaga, 2018). Mahasiswa yang masuk dalam kuadran 2 ini sangat tepat jika diberikan kepercayaan mempimpin dalam sebuah manajemen. Hal ini dipengaruhi dari personal atau karakteristik kepemimpinan yang berorientasi pada tugas maupun hubungan antar anggota tim. Mahasiswa tersebut mampu menentukan tujuan yang akan dicapai, menyusun visi misi, dan menjadi role model bagi anggota tim dalam mencapai tujuan.

Selain gaya dasar terpadu terdapat pula gaya dasar pengabdi walaupun rendah. Gaya dasar pengabdi ini masuk pada kuadran 1 . Kuadran 1 menunjukkan orientasi pada tugas atau pekerjaan yang tinggi dan orientasi pada hubungan atau orang yang rendah. Reddin menjelaskan gaya pengabdi secara gaya efektif masuk pada gaya otokratis yang baik. Otokratis yang baik adalah pemimpin yang memberikan perhatian maksima pada tugas dan minimal pada hubungan kerja. Pemimpin ini menggunkan gaya ini mengetahui secara tepat yang diinginkan dan cara mencapainya tanpa menyebabkan keengganan pihak bawahannya (Adiwilaga, 2018). Mahasiswa yang masuk dalam kuadran 1 ini erat hubungannya dengan hasil efektivitas kepemimpinan. Mahasiswa tersebut memiliki arah yang kurang efektif dalam memimpin, sehingga akan menimbulkan kepemimpinan yang penuh kompromi. Seperti yang dijelaskan Reddin (dalam Adiwilaga, 2018) bahwa gaya yang tidak efektif pada gaya dasar pengabdi yakni gaya pecinta kompromi. Gaya ini menggambarkan pemimpin memberikan perhatian yang besar pada tugas pekerjaan dan hubungan kerja berdasarkan kompromi. Pemimpin ini dalam pembuat keputusan jelek (tidak baik) karena banyak tekanan bawah yang memengaruhinya.

Gaya terakhir yang didapat dari hasil tes kepemimpinan ini adalah gaya berhubungan atau kuadran 3. Gaya berhubungan yang terdapat pada mahasiswa termasuk sangat rendah. Gaya berhubungan yang terjadi memiliki nilai efektivitas kepemimpinan yang tinggi. Hal ini menjadikan gaya berhubungan masuk dalam gaya efektif pecinta pengembang. Gaya pecinta pengembang dijelaskan bahwa pemimpin memberikan perhatian maksimal pada hubungan kerja dan minimal terhadap tugas. Pemimpin yang menggunakan gaya ini mempunyai kepercayaan implisit terhadap orang-orang yang bekerja dalam birokrasi dan sangat memperhatikan pengembangan individu (Adiwilaga, 2018). Mahasiswa yang termasuk dalam gaya ini menjadi pemimpin yang efektif karena mengembangkan anggota tim untuk dapat membantu ketercapaian tujuan organisasi 


\section{KESIMPULAN}

Adapun kesimpulan dari penelitian ini adalah,

1. Tingkat kepemimpinan dasar pada mahasiswa Program Studi Akuntansi Angkatan 2017 UNIBI yang mengikuti kelas Global Leadership memiliki tingkat yang tinggi sebesar $66,6 \%$ pada gaya dasar terpadu atau eksekutif. Selain itu terdapat gaya dasar pengabdi atau pecinta kompromi yang rendah sebesar $26,6 \%$, dan gaya dasar berhubungan atau pecinta pengembang yang sangat rendah sebesar $6,6 \%$. Tingkat kepemimpinan dasar pada mahasiswa mayoritas tinggi pada kepemimpinan yang berorientasi pada tugas dan hubungan anggota tim.

2. Tingkat kepemimpinan efektif pada mahasiswa Program Studi Akuntansi Angkatan 2017 UNIBI yang mengikuti kelas Global Leadership memiliki kepemimpinan efektif yang tinggi sebesar $73 \%$, sedangkan kepemimpinan yang kurang efektif sebesar $27 \%$ yang berarti rendah. Oleh karena itu mahasiswa tersebut dapat memimpin secara efektif karena potensi yang dimiliki untuk memimpin sudah sesuai dengan karakteristik masing-masing personal.

Adapun saran untuk penelitian ini secara teoritis diperlukan teori penguat untuk menganalisis tipe kepemimpinan khususnya di bidang keilmuan komunikasi. Secara praktis penelitian ini masih memerlukan pengembangan penelitian dengan jumlah sampel yang besar untuk penelitian dengan pendekatan kuantitatif. Selain itu, penelitian ini dapat dikaji lebih mendalam mengenai penelitian dengan metode eksplansi korelasi antar faktor atau regresi untuk memprediksi faktor-faktor yang memengaruhi tipe kepemimpinan. 


\section{REFERENSI}

Adiwilaga, Rendy. 2018. Kepemimpinan Pemerintahan Indonesia : Teori dan Praktek. Yogyakarta : Deepbulish.

Bertocci, David I. 2009. Leadership in Organizations: There is a Difference Between Leaders and Managers. Maryland : University of America.

Kaplan dan Norton. 2001. The Strategy Focused Organization: How Balanced Scorecard Companies Thrive In The New Business Environment. Amerika : Harvad Business School Press.

Kriyantono, Rachmat. 2006. Teknik Riset Komunikasi. Jakarta: Kencana Prenada Media Group.
Nyoto. 2019. Manajemen Sumber Daya Manusia. Ponorogo : Uwais Inspirasi Indonesia.

Rizki, Avuan Muhammad. 2018. 7 Jalan Mahasiswa. Sukabumi: Tim CV Jejak.

Sudijono, Anas. 2007. Pengantar Statistik Pendidikkan. Jakarta: PT. RajaGrafindo Persada.

Storey, John. 2004. Leadership In Organizations Current Issues and Key Trends. New York: Routledge.

Thoha. 2001. Perilaku Organisasi: Konsep dan Aplikasinya. Jakarta: RajaGrafindo Persada. Sumber lain

https:/ensiklopediapramuka.com 